\title{
Speech Function in Onang- onang
}

\author{
Linda Efrina Nasution \\ English Applied Linguistic Study Program \\ Post Graduate School, Universitas Negeri Medan \\ Medan, Indonesia \\ 1.efrina@yahoo.com \\ Busmin Gurning \\ English Applied Linguistic Study Program \\ Post Graduate School, Universitas Negeri Medan \\ Medan, Indonesia \\ Rahmad Husein \\ English Applied Linguistic Study Program \\ Post Graduate School, Universitas Negeri Medan \\ Medan, Indonesia \\ rhnapitupulu@yahoo.com
}

\begin{abstract}
This study addresse analysis of Speech Function in Onang- onang. The main objectives of this study was to investigate the kinds of Speech Function in Onang- onang. This study based on descriptive qualitative approach. The data were collected by applying documentary technique. The data were the utterances consisting of clauses in Onang - onang. The data were analyzed based on the theory of Speech Function proposed by Halliday, there were found 96 data of seven kinds of Onangonang. The result of this study revealed there are three kinds of Speech function that mostly appeared in Onang - onang, which are statement, command and offer. Statement is the most dominant kind of Speech function realized in Onang - onang.
\end{abstract}

Keywords-Speech Function, Onang - onang

\section{INTRODUCTION}

\section{A. Background of The Study}

Language is needed in communication to other people in particular setting. The role of the language in communication can be spoken or written. Sometimes language is used to enact the personal or the social relationship around the speakers. The general function of language is known as Metafunction. To represent our experience, to enact the relationships and to organize discourse as a meaningful text. The Systemic Functional Linguistics study recognize three kinds of Metafunctions named textual, interpersonal and ideational metafunctions. Halliday and Matthiessen state that sometimes language is used to enact our personal and social relationship with the other people around us ${ }^{[1]}$, this function of language is called interpersonal metafunction. It means interpersonal metafunctions shows us the speakers attitudes toward their relationship in personal and social interactions with the listener.
In Systemic Functional tradition Halliday describes language is used to establish the relationship between the speaker and the listener, in the act of speaking the speaker adopts for himself a particular speech role in the exchange ${ }^{[2]}$. The basic speech role is giving and demanding divides into information and good or services. When the roles and the commodities involved the interaction four speech functions are derived, statement, question, offer and command. Language can spoken or written, in delivering his speech the speaker taking a role wheater to seek information or giving information or demanding good or services.

Analyzing Speech function in Onang - onang was the conceptual backbone of this reserch. Onang - onang is the oral literature that usually found in the wedding ceremony in North Padang Lawas regency. Onang - onang is cultural song that usually sung by a singer which is called "Paronang - onang". It usually sung to accompany a traditional dance named Tortor. The lyrics of Onang - onang describes about the relationships of one person with others. For instance Onang onang Suhut desribes about the relationship of Suhut as the group of Tor-tor dancer, their names, their social status, their family, their loves and their hopes to the wedding couple and the family that held the ceremony.

In the semantic aspect the four speech functions find their realization in Mood. Halliday and Matthiesen say Mood is the major interpersonal system of the clause; it provides interactants involved in dialogue with the resources for giving or demanding a commodity, either information or goods-\&services $^{[1]}$. In other words, with the resources for enacting speech functions (speech acts) through the grammar of the clause: statements (giving information), questions (demanding information), offers (giving goods- $\&$-services), and commands (demanding goods- $\&$-services). 
Giving means "inviting to receive” and demanding means "inviting to give". The commodity that giving or demanding are "good and services" and "information". The speaker is not only doing something himself; he is also requiring something of the listener. Typically, therefore, an 'act' of speaking is something that might more appropriately be called an interact: it is an exchange, in which giving implies receiving and demanding implies giving in response.

In delivering his speech in interaction the Paronang onang (Onang - onang singer) should modify his speech role, because sometimes the participant in the wedding ceremony especially the Tor - tor dancers are older and has higher social status than him, for instance they are elders in the cultural community or the owner of the occasion. Interacting with them Paronang - onang should use polite language. Ordering or commanding person with higher social status should use polite language, this position make Paronang - onang should modify his language in order to get the polite language. In order to get information and data about the speech roles that Paronang onang take in delivering his songs, the writer would like to conduct further research about Speech function in Onang onang.

\section{B. The Problem of the Study}

The problem of this research can be formulated as follow:

1. What kinds of Speech functions were used in Onangonang?

2. What is dominant kinds of Speech function used in Onang - onang?

\section{REVIEW OF LITERATURE}

\section{A. Interpersonal Metafunction}

Bloor and Bloor state language used to enable us to participate in communicative acts with other people, to take on roles and to express and understand feelings, attitude and judgements ${ }^{[3]}$. This function is known as the interpersonal metafunction. It means interpersonal metafunction is the function of language that we use in communication with other people to built interaction. Halliday and Matthiessen state that Interpersonal function is the function to enact the social process or human relationship using language ${ }^{[1]}$. The Halliday and Matthiessen opinion above also said that interpersonal metafunction help human built their relationship each other by using languge.

The function of interpersonal is the action by the language users in exchanging experience linguistic unpresentable in function of experience (experiental meaning). It means in interpersonal metafunction perspective, human used language to exchanging their need in information, goods or services.

\section{B. Roles of Addressers and Audience (Speech Function)}

The other material that related to the analysis of the interpersonal metafunction is the type of speech roles. In this study, the writer wants to know the kinds of speech roles in the lyrics of Onang - onang and which one the most dominant is used in Onang - onang. Halliday said "language itself defines the roles which people may take in situations in which they are communicating with one another; and every language incorporates options whereby the speaker can vary his (or her) own communication role, making assertions, asking questions, giving orders, expressing doubts and so on" [4]. Saragih also states that speech function refers to a function performed by a speaker in a verbal interaction or conversation which specifies his or her role and the content or commodity transacted ${ }^{[5]}$.

When people interact with other person, we not only use language to exchange information, to argue about whether things are or are not. We also use language to influence each other's behaviour. Human interaction recognized two categories for using language to exchange goods and services; giving goods and services (which gave us the speech function offer), and demanding goods and services (which gave us the speech function command).

TABLE 2.1 Basic Speech Roles

\begin{tabular}{|c|c|c|}
\hline Role in exchange & $\begin{array}{c}\text { Commodity } \\
\text { Goods \& } \\
\text { services }\end{array}$ & Information \\
\hline Giving & Offer & Statement \\
\hline Demanding & Command & Question \\
\hline
\end{tabular}

Table above shows that a statement is any stretch of language that functions to give information to the addressee; a question is any stretch that functions to elicit information from the addressee; a command is any stretch whose intended function is to influence the behaviour of the addressee in some way; and offer is any stretch whose function is to initiate or accompany the giving of goods- $\&$-services to the addressee.

The semantic function of a clause in the exchange of information is a proposition and the semantic function of a clause in the exchange of goods- $\&$-services is a proposal. Halliday and matthiesen state when language is used to exchange information, the clause takes on the form of a proposition ${ }^{[1]}$. It becomes something that can be argued about - something that can be affirmed or denied, and also doubted, contradicted, insisted on, accepted with reservation, qualified, tempered, regretted, and so on. Unlike statements and questions, when language used to exchange goods or services, the clause takes on the form of proposal because they cannot be affirmed or denied.

\section{Onang - onang}

Onang-onang is kind of songs that exist in North Padang Lawas. Onang- onang is played in traditional ceremony especially in wedding ceremony of North Padang Lawas ethnic community. North Padang Lawas ethnic community has its own customs, culture and language. They speak Angkola language. Angkola language itself is closely related to Mandailing and Batak Toba language. The researcher choose to analyze Onang- onang songs that played in North Padang Lawas Regency.

Hutasuhut says that Onang-onang is a traditional arts in Batak Angkola ethnic community which is sung in the huge wedding celebration (margondang) ${ }^{[6]}$. The implementation of Onang- onang usually accompanied by playing instrumental music namely Gondang. Onang-onang is a song that played 
in a traditional dance named Tor tor. Tor tor is always played by using Gondang and Onang-onang.

The lyric of Onang- onang always started by word "oi sonang baya onang", that means "very happy to remember". The singer of Onang- onang is called Paronang- onang. Paronang-onang has to know the purpose of the ceremony, and he also has to know to whom he sing Onang-onang, because there is a different lyric of Onang- onang based on the subject that sing into.

As a song Onang- onang does not have particular lyric, Paronang- onang compose the lyric of Onang-onang spontanically and in the form of poem, that is why before sing an Onang-onang, Paronang-onang should know the purpose of the ceremony, to whom the Onang-onang will be intended, the background of the subject that in Onang-onang, because different person will have different Onang- onang lyric of songs.

The lyric of Onang-onang song consist of 1) introduction, 2) the explanation of the purpose of the ceremony, 3) the explanation about the background of the Tor - tor dancer, 4) praise, 5) advice and 6) prayer or hope. Paronang- onang creates the lyric in form of verses that has deep meaning that describes the journey of the Tor-tor dancer life.

The wedding ceremony in North Padang Lawas is called "mata ni horja" various kinds of Tor- tor dancing are presented, starting from Tor- tor ni suhut, Tor - tor Anak Boru, Tor - tor Pisang Raut, Tor - tor Mora, Tor - tor Raja Panusunan Bulung, Tor- tor Naposo Nauli Bulung and closed by Tor-tor Bayo Pangoli and Boru Nadioli. All those kinds of Tor - tor is accompanied by Onang-onang for suhut, Onangonang for Anak Boru, Onang- onang for Mora, Onangonang for Raja Panusunan Bulung, and Onang- onang for Naposo nauli bulung and Onang - onang Bayo Pangoli and Boru Nadioli. When the Tor - tor Pisang Raut is presented, its not accompanied by Onang- onang, the song that accompanied Tor - tor Pisang Raut is called Endeng-endeng. Endeng-endeng is kind of song that in form of funny poem to accompanied Tor-tor Pisang Raut.

The social system in North Padang Lawas is influenced by North Padang Lawas cultural community which is known as "Dalihan Natolu". Lubis said that Dalihan Natolu is a community of Mandailingnese cultural in society which is consist of Suhut and its Kahanggi, Mora, and Anak Boru ${ }^{[7]}$.

Suhut and their Kahanggi, Nasution says that Suhut and Kahanggi is a grup of family that has same surename in a village as the founder of the village. Suhut are the parties that held the ceremony and Kahanggi is the brother or the cousin of the Suhut that has same sure name ${ }^{[8]}$. Mora, are the families of the girls in the marriage. Anak Boru, is the family that marrying a girl in one family in another word Anak Boru is a groom's family

Practically, Dalihan natolu have same positions in the society, because a person can be a Suhut in their own ceremony, Mora for another family, and also can be Anak boru for another situation. In making decision, Dalihan natolu have the same rights, like three - foot furnace. two foots will not be useful if one foot is broken, same with the situation anak boru will be useless without Mora and Suhut. Besides Suhut, Mora and Anak Boru as major aspect of Dalihan Natolu, the social cultural community also have another terms to express their relationship in the community, they are Pisang raut and Kahanggi. Pisang raut is the niece and nephew of the Suhut, in the wedding ceremony Pisang raut also take a part as Tor-tor dancer which is accompanied by Endeng-endeng Pisang raut. Kahanggi is the person that help Suhut in held the wedding ceremony. Similarly with Pisang raut, Kahanggi also take part in wedding ceremony as Tor-tor dancer which is accompanied by Onang- onang Kahanggi.

\section{RESEARCH METHOD}

The research design of this study is descriptive qualitative by using case study approach in order to describe Speech function in Onang - onang. According to Bogdan and Biklen, a qualitative method has a natural setting as the direct source of data ${ }^{[9]}$. The qualitative means to find out how theory works in different phenomenon whose data collected are in the words rather than number. This research is designed with single case system, where it was conducted only in Onang-onang.

The data of this research were the utterances consisting of clauses in Onang- onang. The lyric of the Onang- onang were separated in to Mood elements. The data of the study were collected by applying documentary technique, a method for collecting the data which is kept in the form of documentation. The procedure of administrating the data are follows:

\section{a. Identifying the lyric of Onang- onang.}

b. Selecting the clauses consisting of praise, prayer and advice in Onang - onang.

c. Categorizing the data, interpreting and making the general findings.

After collecting the data, the writer analyzed it by using steps adapted from Miles, Huberman and Saldana (2014) interactive model. This technique of analyzing the data consist of data collection, data condensation, data display, conclusion drawing/ verifying. There are seven kinds of Onang - onang songs that analyzed in this research, each of data is coding in such a way. Saldana (2009:3) says that "a code in qualitative inquiry is most often a word or short phrase that symbolically assigns a summative, salient, essence capturing, and / or evocative attribute for a portion of language - based or visual data". Onang- onang Suhut male is coded by SFO. SM, Onang- onang Suhut female is coded by SFO. SF, Onangonang Mora is coded by SFO.M, Onang-onang Anak Boru is coded by SFO.AB, Onang-onang Raja Panusunan Bulung is coded by SFO.RPB, Onang- onang Naposo Nauli Bulung is coded by SFO.NNB and then Onang- onang Bayo Pangoli and Boru Nadioli is coded by SFO. BP. Each of datum was coding by the name of the Onang-onang and the number of the datum, such as the datum of Onang- onang Suhut male number one is coded by SFO.SM01.

\section{RESEARCH FINDINGS}

The research findings in this study includes the kinds of Speech Function in Onang- onang and kinds of Speech function that dominantly used in Onang - onang. Each of the findings is given separately below: 


\section{A. Kinds of Speech Function}

After found and transcribing the lyric of Onang - onang, the next step is divided the data into clauses in related to the praises, prayer and advice. Each of data were analyzed based on the Speech function statement, offer, question and command.

After having analyzed the data, it can be known that the kinds of Speech Function used in Onang- onang are statement, command and offer. The analysis has found that statement mostly appears in this song, the second command whereas offer only appears once. The using of speech function in Onang-onang indicates that the main function of Onangonang is to give information. Paronang-onang as the speaker states and declares some information about the family and the wedding couple to the listener which are consist of Tor - tor dancer and the participant in the wedding ceremony. While command is used to create an order to all the participant in wedding ceremony to do some instruction to fulfill the speaker's intention. Offer is used to initiate or accompany the services that the speaker gives to the ceremony. The example of Speech Function in Onang - onang can be seen in the following example.

a. Datum SFO. SM04

Almarhum amatta tongku usman i da lapang mada di dalam kubur i

\begin{tabular}{|l|l|l|l|}
\hline S & F & P & Comple \\
\hline Mood & Residu \\
\hline \multicolumn{3}{|c|}{ Statement } \\
\hline
\end{tabular}

b. Datum SFO. SF11

Manortor inatta soripada i da dalan da mandoa tu Tuhan i

\begin{tabular}{|c|c|c|cc|}
\hline P & S & F & C \\
\hline & \multicolumn{3}{|c|}{ Mood } & Residu \\
\hline \multicolumn{4}{|c|}{ Statement } \\
\hline
\end{tabular}

c. Datum SFO.SM02

Attong angkat bo jari sappulu i

\begin{tabular}{|l|l|l|l|}
\hline AJ & P & F & Comple \\
\hline \multicolumn{3}{|c|}{ Command } \\
\hline \multicolumn{3}{|c|}{ Residu } \\
\hline
\end{tabular}

d. Datum SFO.SF01

Muda adong on baya hata na lilu i mangido maaf hamu parjolo $i$

\begin{tabular}{|c|c|c|c|c|}
\hline $\mathrm{S}$ & $\mathrm{F}$ & $\mathrm{C}$ & $\mathrm{P}$ & $\mathrm{C}$ \\
\hline \multicolumn{3}{|c|}{ Residu } & \multicolumn{2}{|r|}{ Mood } \\
\hline \multicolumn{5}{|c|}{ Command } \\
\hline
\end{tabular}

e. Datum SFO.SM01

$\mathrm{Hu}$ tolong baya hu doa jolo on atco borkat da baya tor tor ale da muyu \begin{tabular}{|c|l|l|l|l|l|l|l|}
\hline S & P & F & S & P & F & Am & C \\
\hline & Residu & Mood & Residu \\
\hline \multicolumn{5}{|c|}{ Offer } \\
\hline
\end{tabular}

\section{B. The Most Dominant Speech Function Realized in Onang - onang.}

There are four kinds of speech functions, offer, command, statement and question. Each of speech function is realized through different clausal structures. The table below shows the kinds of Speech Function used in Onang- onang.
TABLE 4.1 The value percentage of Speech Function in Onang-onang

\begin{tabular}{|c|c|c|c|c|c|}
\hline \multirow{2}{*}{ No. } & \multirow{2}{*}{$\begin{array}{c}\text { Kinds of } \\
\text { Onang-onang }\end{array}$} & \multicolumn{4}{|c|}{ Speech Functions (\%) } \\
\hline & & $\mathrm{S}$ & $\mathrm{O}$ & $\mathrm{Q}$ & $\mathrm{C}$ \\
\hline 1. & $\begin{array}{l}\text { Onang-onang } \\
\text { Suhut Male }\end{array}$ & $88.46 \%$ & $3.85 \%$ & $0 \%$ & $7.69 \%$ \\
\hline 2. & $\begin{array}{l}\text { Onang-onang } \\
\text { Suhut Female }\end{array}$ & $77.77 \%$ & $0 \%$ & $0 \%$ & $22.22 \%$ \\
\hline 3. & $\begin{array}{c}\text { Onang-onang } \\
\text { Mora }\end{array}$ & $57.14 \%$ & $0 \%$ & $0 \%$ & $42.85 \%$ \\
\hline 4. & $\begin{array}{c}\text { Onang-onang } \\
\text { Anak Boru }\end{array}$ & $63.63 \%$ & $0 \%$ & $0 \%$ & $36.37 \%$ \\
\hline 5. & $\begin{array}{c}\text { Onang-onang } \\
\text { Raja } \\
\text { Panusunan } \\
\text { Bulung }\end{array}$ & $80.00 \%$ & $0 \%$ & $0 \%$ & $20.00 \%$ \\
\hline 6. & $\begin{array}{l}\text { Onang-onang } \\
\text { Naposo Nauli } \\
\text { Bulung }\end{array}$ & $42.85 \%$ & $0 \%$ & $0 \%$ & $57.14 \%$ \\
\hline 7. & $\begin{array}{l}\text { Onang-onang } \\
\text { Bayo Pangoli }\end{array}$ & $66.66 \%$ & $0 \%$ & $0 \%$ & $33.33 \%$ \\
\hline
\end{tabular}

From the table above, it is shown the speech function that mostly dominated by statement, the second is command and offer while question is not appear in Onang-onang songs. In Onang- onang Suhut Male $88.46 \%$ of data are statement, $3.85 \%$ of data are offer then $7.69 \%$ of data are command. In Onang-onang Suhut Female $77.77 \%$ of data are statement, while $22.22 \%$ of data are command, there is no offer and question in Onang- onang Suhut female. The third song Onang-onang Mora shows $57.14 \%$ of data are statement and $42.85 \%$ of data are command, we can not find offer and question in this data. Then, in Onang - onang Anak Boru the researcher found $63.63 \%$ of data are statement and the rest of data $36.37 \%$ are command. Onang- onang Raja Panusunan Bulung used $80 \%$ of Statement and $20 \%$ of data are command. The table above also shows that Onang - onang Naposo Bulung used $42.85 \%$ of its lyrics are statement and command 57.14\%. Then the last song Onang -onang Bayo Pangoli, uses $66.66 \%$ of statement and $33.33 \%$ of command, this data does not have offer and question either.

Based on the definition above it is obvious that Speech Function of statement was dominantly used in Onang-onang. In means the role of the speaker in Onang - onang dominantly is to inform the information to the listener. The task of Paronang - onang as the speaker here is to giving infomation to the visitor in the ceremony. The information that being exchanged here are the names of the family member, their jobs, their social status. Paronang - onang describe the name of the Tor- tor dancer and also praise them politely. The second Speech function that realize in Onang - onang is Command. Beside giving information the speaker also demanding goods and services, it means the Paronang onang is asking the listener to do something what he said in Onang - onang lyrics. Demanding goods and services in Onang - onang can be seen when the Paronang - onang asking the Tor-tor dancer to make some action such raise your hand, do a prayer and asking for forgiveness. In the Onang - onang Suhut Female its found that there is a datum in the form of Offer, in the datum SFO.SM01 the Paronang - 
onang is giving goods and service by help the Suhut in leading the ceremony and also pray for them.

The data of Speech Function in Onang - onang shows that the commodity that being exchange are giving informatin (statement), demanding goods and services (command) and then giving goods and services (offer).

\section{Discussions}

After arranged the finding, there are some points of the findings need to be discussed as the improvement or rejections towards the theories or previous research drawn. Based on the data it can be found that Speech Function of Statement and declarative Moods are dominantly used in Onang- onang. In means the role of the speaker in Onang - onang dominantly is to inform the information to the listener. Paronang - onang as the speaker in the interaction giving information about the Tor - tor dancer and all the participant in the ceremony. The information that being shared can be the name, social status, wealthiness, education and their life story. Speech function Command also realized in the Onang- onang, but not as dominant as Statement. In the term of clause as an exchange the commodity that being exchanged in Command is demanding Goods and services, the speaker used the Command in ordering the participant to do something, for instance in starting the Tor-tor, the dancers are asked to raise their hands. The Paronang- onang also used Command when he gave the advice to the Tor - tor dancer and all the participant of the ceremony. Besides Statement and Command, the Speech Function Offer also occur once in Onang - onang. The commodity that being exchanged in Speech Function Offer is giving Goods and services. The speaker used Offer once when he proposes to make a prayer before start the ceremony.

Clause as an exchange is about the relationship between speakers and listener through the form of language. Halliday said "language itself defines the roles which people may take in situations in which they are communicating with one another; and every language incorporates options whereby the speaker can vary his (or her) own communication role, making assertions, asking questions, giving orders, expressing doubts and so on" ${ }^{[4]}$. Saragih also states that speech function refers to a function performed by a speaker in a verbal interaction or conversation which specifies his or her role and the content or commodity transacted ${ }^{[5]}$. The experts above view that the role of clause as exchange is a tool to interact or means of exchange which is involve "giving" and "demanding".

Gerot and Wignell "if a speaker gives you some information, she is inherently inviting you to receive that information $^{[9]}$. If a speaker offers you some goods or services, the speaker is inherently inviting you to receive those goods and services. Or if she or he demands information of you, inherently you are invited to give that information. And if she or he demands some goods or services of you, you are thereby invited to render that service or provide the goods.

Giving means "inviting to receive" and demanding means "inviting to give". The commodity that giving or demanding are "good and services" and "information". The speaker is not only doing something himself; he is also requiring something of the listener. Typically, therefore, an 'act' of speaking is something that might more appropriately be called an interact: it is an exchange, in which giving implies receiving and demanding implies giving in response.

\section{CONCLUSION AND SUGGESTION}

\section{A. Conclusion}

This study has done in such deliberately way. It is now to conclude the result of this study as follows:

a. There are two kinds of speech function that occur in Onang- onang. They are statement and command. The most dominant speech function that occur in Onangonang is statement. It indicates the main function of Onang-onang is giving information.

b. The process of realization of speech function in Onangonang are realised congruently in Mood, the congruent realization of Spech Function can be seen from the Speech function Statement realized in declarative mood and Command is realized in Imperative Mood.

c. The construction of structure of the clause in Onang onang is adopt the North Padang Lawas language structure which usually begin from predicator first. Based on the SFL theory for Speech function Statement the Mood elements was seem incongruent, but for Speech function Command the Mood elements based on North Padang Lawas clause seem congruent.

d. The context or the reason of the realization of speech function is influenced by the social determinant and ideology that exist in North Padang Lawas cultural community. Speech function in Onang- onang song realize in the way they are because of the power initiation, the politeness need and difference of language structure between English and North Padang Lawas Languge.

\section{B. Suggestion}

As the conclusions has taken the place, there are some suggestions presented due to this study:

a. It is suggested that the speakers should clearly use exact Speech function to describe the purpose of their speech in order to avoid the misunderstanding in communication

b. Respectifully to readers of this study, speech function is a shortcut to recognize and identify the speech role of someone in communication. To find out the speech role and power that exist in comunication, the reader have to make sure the context and ideology in the society.

\section{REFERENCES}

[1] Halliday, M.A.K and C.M.I.M Matthiessen. 2014. An Introduction to Functional Grammar (fourth Edition), New York: Routledge. Pp.106154

[2] Halliday, M.A.K. 1994. An Introduction to Functional Grammar Second Edition, New York: Edward Arnold. P. 68

[3] Bloor and Bloor. 2004. The Functional Analysis of English a Hallidayan Approach, (Second Edition). Great Britain: Arnold A. p.9

[4] Halliday, M.A.K. 2002. Language Structure and Language function, in J. Webster, ed., on Grammar, London: Continuum.

[5] Saragih. A. 2013. Discourse Analysis A Study on Discourse Based on the Systemic Functional Linguistic Theory, Medan: Unimed Press. Pp.17-21

[6] Hutasuhut, F.M. 2015. Nukilan Budaya Etnik Batak Angkola Mandailing, Medan: Perpustakaan Kota Medan.

[7] Lubis, S. 1997. Adat Hangoluan Mandailing Tapanuli Selatan, Medan.pp 90-100 
[8] Nasution, H. Pandapotan. 2005. Adat Mandailing Dalam Tantangan Zaman. Sumatera Utara: FORKALA.. p. 82
[9] Gerot, L and P. Wignell. 1994. Making Sense of Functional Grammar, Australia: Gerd Stabler. Pp.21-42 